ISSN: $0069-0058$

E-ISSN: $1925^{-0169}$

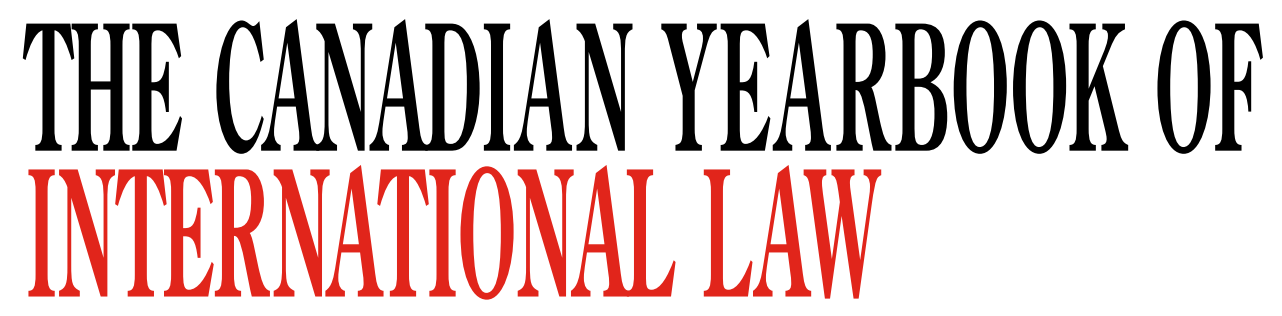

VOLUME $58 \quad 2020 \quad$ TOME 58

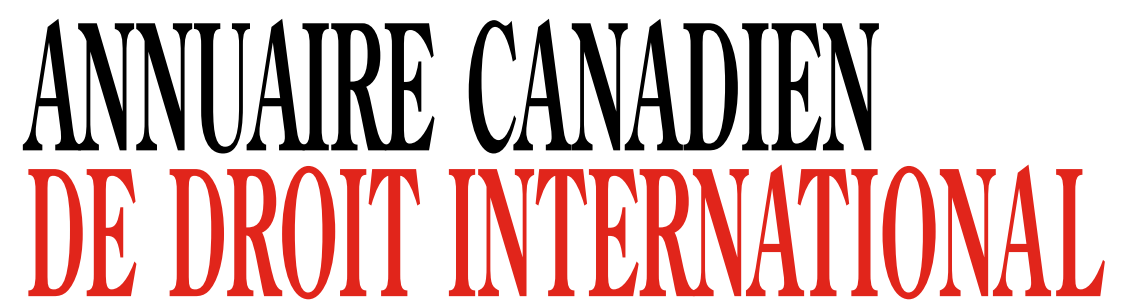

CAMBRIDGE UNIVERSITY PRESS 


\section{THE CANADIAN YEARBOOK OF INTERNATIONAL LAW \\ VOLUME $5^{8} \quad 2020$ TOME $5^{8}$ \\ ANNUAIRE CANADIEN \\ DE DROIT INTERNATIONAL}




\section{The Canadian Yearbook of International Law Annuaire canadien de droit international}

Established in 1961, The Canadian Yearbook of International Law is a leading international academic journal covering both public and private international legal issues. Authors from Canada and around the world are invited to publish peer-reviewed articles in French or English that advance critical thinking in all areas of international law. The Canadian Yearbook of International Law also seeks to make Canadian practice in international law accessible to academics, policy-makers, and practitioners. Issued annually under the auspices of the Canadian Council on International Law, the Yearbook contains articles of lasting significance in the fields of public and private international law; a notes and comments section; a digest of Inter-American law; a digest of international economic law; a section on current Canadian practice in international law (including recent parliamentary declarations, Canadian treaty actions, and positions stated by Canada's Department of Global Affairs); a digest of important Canadian cases in the fields of public and private international law; and a book reviews section.

Fondé en 1961, l'Annuaire canadien de droit international est une revue internationale réputée qui se spécialise dans les questions de droit international public et privé. Ses auteurs et auteures, en provenance du Canada et de partout dans le monde, sont invités à publier des articles en français comme en anglais, évalués par des pairs et qui mettent de l'avant une pensée critique dans tous les domaines du droit international. L'Annuaire canadien de droit international cherche aussi à rendre la pratique canadienne du droit international accessible aux universitaires, aux responsables de politiques publiques ainsi qu'aux praticiens et praticiennes. Publié annuellement sous les auspices du Conseil canadien de droit international, l'Annuaire comprend des articles de fond dans le domaine du droit international public et privé, une rubrique de notes et de commentaires, une chronique sur le droit interaméricain, une chronique de droit international économique, une rubrique sur la pratique canadienne en droit international (y compris les récentes déclarations au Parlement, les positions canadiennes sur les traités et les positions du ministère canadien des Affaires mondiales), un recueil de la jurisprudence canadienne relative au droit international public et privé, et une rubrique de recensions d'ouvrages.

From Volume 52, The Canadian Yearbook of International Law is published by Cambridge Journals under the auspices of the Canadian Council on International Law. Print copies of Volumes 1 to 51 are available from UBC Press. The complete online archive of the Yearbook can be found at https://www.cambridge.org/cyil.

Dès le tome 52, l'Annuaire canadien de droit international est publié par Cambridge Journals sous les auspices du Conseil canadien de droit international. Veuillez vous adresser à UBC Press pour des exemplaires imprimés des tomes 1 à 51. Les archives électroniques complètes de l'Annuaire se trouvent à https://www.cambridge.org/acdi.

ISSN: 0069-0058

E-ISSN: 1925-0169

(c) The Canadian Yearbook of International Law / Annuaire canadien de droit international 2021 


\title{
Board of Editors Comité de rédaction
}

\author{
Editor-in-Chief Directeur \\ JOHN H. CURRIE \\ University of / Université d'Ottawa, Canada
}

\author{
Associate Editor Directeur associé \\ RENÉ PROVOST \\ McGill University, Canada
}

Assistant Editor Directrice adjointe

JOANNA HARRINGTON

University of Alberta, Canada

Members of the Board

JOOST BLOM

University of British Columbia, Canada

VALERIE HUGHES

Queen's University, Canada

MAUREEN IRISH

University of Windsor, Canada

HUGH KINDRED

Dalhousie University, Canada

HON. EDWARD M. MORGAN

Superior Court of Justice of Ontario, Canada
Membres du Comité

FRANCE MORRISSETTE

Université d'/University of Ottawa, Canada

ALAIN PRUJINER

Université Laval, Canada

LINDA C. REIF

University of Alberta, Canada

J. CHRISTOPHER THOMAS, Q.C.

National University of Singapore, Singapore

STEPHEN TOOPE

University of Cambridge, United Kingdom

DANIEL TURP

Université de Montréal, Canada

\author{
Honorary Editors \\ Directeurs honoraires \\ J.-G. CASTEL, Q.C. \\ York University, Canada \\ HON. G.V. LA FOREST, Q.C. \\ Supreme Court of Canada, Canada \\ ARMAND DE MESTRAL \\ D.M. MCRAE \\ McGill University, Canada \\ University of / Université d'Ottawa, Canada
}

JACQUES-YVAN MORIN

Université de Montréal, Canada

The Board of Editors and the Canadian Council on International Law are not in any way responsible for the views expressed by contributors, whether the contributions are signed or unsigned.

Les opinions émises dans le présent Annuaire par nos collaborateurs, qu'il s'agisse ou non d'articles signés, ne sauraient aucunement engager la responsabilité du Comité de rédaction ou du Conseil canadien de droit international. 
Submission guidelines: All English language submissions should be sent electronically to: john.currie@uottawa.ca or by ordinary mail to Professor John Currie, The Editor-inChief, The Canadian Yearbook of International Law, Faculty of Law, Common Law Section, University of Ottawa, 57 Louis Pasteur Street, Ottawa, Ontario K1N 6N5, Canada. The Yearbook has a rolling acceptance policy and benefits from FirstView, a feature offered through the Cambridge Journals Online platform. It allows completed pieces to be hosted online prior to their inclusion in a final print and online journal issue. This significantly reduces the lead time between submission and publication. For more detailed information and style instructions see https://www.cambridge.org/cyil.

Protocole pour la soumission de textes: Prière de soumettre tout texte rédigé en français en format électronique à: rene.provost@mcgill.ca ou par la poste au Professeur René Provost, Directeur associé, Annuaire canadien de droit international, Faculté de droit, Université McGill, 3674 rue Peel, Montréal, Québec H3A 1W9 Canada. L'Annuaire suit une politique d'acceptation continue et a accès à FirstView, une fonction offerte par l'intermédiaire de la plate-forme en ligne de Cambridge Journals. Cette fonction permet d'héberger des textes complets en ligne avant leur inclusion dans une publication finale imprimée et en ligne. Ceci permet de réduire énormément le délai entre la soumission et la publication. Pour des consignes de rédaction détaillées, visitez https://www.cambridge.org/acdi.

Subscriptions: 2021 subscription price: online and print subscription: US\$341 in the USA, Canada and Mexico; UK £214 + VAT elsewhere. Online-only subscription: US\$280 in the USA, Canada and Mexico; UK $£ 175$ + VAT elsewhere. Print-only subscription: US\$309 in the USA, Canada and Mexico; UK £195 + VAT elsewhere. Subscription correspondence and address changes should be sent to: Cambridge University Press, One Liberty Plaza, 20th Floor, New York, NY 10006, USA, email subscriptions_newyork@cambridge.org, for customers in the USA, Canada and Mexico. Customers elsewhere should contact: Cambridge University Press, University Printing House, Shaftesbury Road, Cambridge CB2 8BS, UK, email journals@cambridge.org. Individual articles to be purchased and rented are also available through Cambridge University Press.

Abonnement: Prix d'abonnement annuel en 2021: version imprimée et électronique: 341 \$US aux États-Unis, au Canada et au Mexique; 214 GBP + TVA ailleurs. Version électronique seulement: 280 \$US aux États-Unis, au Canada et au Mexique, 175 GBP + TVA pour les autres pays. Version imprimée seulement: 309 \$US aux États-Unis, au Canada et au Mexique; 195 GBP + TVA pour les autres pays. Prière d'envoyer toute correspondance relative aux abonnements et les changements d'adresse à Cambridge University Press, One Liberty Plaza, 20th Floor, New York, NY 10006, USA, adresse électronique subscriptions_newyork@cambridge.org, pour les clients résidant aux États-Unis, au Canada et au Mexique. Les clients d'autres pays sont priés d'utiliser l'adresse: Cambridge University Press, University Printing House, Shaftesbury Road, Cambridge CB2 8BS, UK, adresse électronique journals@cambridge.org. L'achat et la location d'articles individuels sont également disponibles en contactant Cambridge University Press.

Permissions information: All rights reserved. No part of this publication may be reproduced, in any form or by any means, electronic, photocopying, or otherwise, without permission in writing from Cambridge University Press. Policies, request forms and contacts are available at: http://www. cambridge.org/about-us/rights-permissions. Permission to copy (for users in the USA) is available from Copyright Clearance Center (http://www.copyright.com, email info@copyright.com).

Information sur les permissions: Tous droits réservés. Toute reproduction de cette publication, en partie ou en entier, par quelque procédé que ce soit (électronique, photocopié ou autre), est interdite sans la permission écrite de Cambridge University Press. Pour de plus amples renseignements, des formulaires de demande et les coordonnées nécessaires, rendez-vous à l'adresse web suivante: http://www.cambridge.org/about-us/rights-permissions. L'autorisation de reproduire (pour les utilisateurs aux États-Unis) peut être demandée du Copyright Clearance Center (http://www.copyright.com, adresse électronique info@copyright.com).

Advertising: To advertise in the Yearbook email USAdSales@cambridge.org or telephone +1 (212) 3375053 in the USA, Canada and Mexico; email ad_sales@cambridge.org or telephone +44 (1223) 325083 in the rest of the world.

Publicité: Pour toute publicité dans l'Annuaire contactez USAdSales@cambridge.org ou téléphonez +1 (212) 3375053 pour les clients résidant aux États-Unis, au Canada et au Mexique; ou contactez ad_sales@cambridge.org ou téléphonez+44 (1223) 325083 pour les clients d'ailleurs.

Indexing / indexage: De Gruyter IBR/IBZ, Proquest, William S Hein \& Co Inc. 


\section{Table of Contents / Table des matières}

\section{Articles}

Indigenous Rights and Trade Obligations: How Does CUSMA's Indigenous General Exception Apply to Canada?

J. Anthony VanDuzer and Melanie Mallet

Le "prolongement naturel" et le plateau continental étendu arctique du Canada: coopérer pour donner sens au droit, à la science et aux faits

Kristin Bartenstein et Laure Gosselin

The Scope of Compulsory Jurisdiction and Exceptions Thereto under the United Nations Convention on the Law of the Sea

Bjørn Kunoy

Lutter autrement contre la corruption transnationale: potentiel et défis du système de sanctions de la Banque mondiale Louisa Grigoryan et Amissi M. Manirabona

Any Port in a Pandemic: International Law and Restrictions on Maritime Traffic during the COVID-19 Pandemic

Justin Okerman and Barbara von Tigerstrom

Un nouveau "cheval de Troie"? Regard sur la codification des normes impératives du droit international général (jus cogens)

Thibault Moulin

The Risk of Obsolescence: Reframing the Contemporary Use of Force Model to Achieve a More Holistic Application of the UN Charter Jus Ad Bellum Construct

Brian L. Cox 
Notes and Comments / Notes et commentaries

Mining for Legal Luxuries: The Pitfalls and Potential of Nevsun Resources Ltd v Araya

Eva Monteiro

Obligations de comportement et obligations de résultat dans la jurisprudence de la Cour internationale de Justice

Tiphaine Demaria

Canada's Pro-Ban Stance on Double-Hatting: Playing the Long Game in ISDS Reform?

Céline Lévesque

Chronique de droit interaméricain en 2020/

Digest of Inter-American Law in 2020

Les développements en droit interaméricain pour

l'année 2020

Bernard Duhaime

408

Chronique de droit international économique en 2020/

Digest of International Economic Law in 2020

Commerce

Hervé A. Prince

435

Investissement

Charles-Emmanuel Côté

Canadian Practice in International Law /

Pratique canadienne en matière de droit international

At Global Affairs Canada in 2020 / Aux Affaires mondiales

Canada en 2020

Alan H. Kessel

Parliamentary Declarations in 2020 / Déclarations parlementaires en 2020

Richard Ositashvili and Alexandra Logvin

Treaty Actions Taken by Canada in 2020 / Mesures prises par le Canada en matière de traités en 2020

Stephen Randall 


\section{Cases / Jurisprudence}

Canadian Cases in Public International Law in 2020 / Jurisprudence canadienne en matière de droit international public en 2020

Gib van Ert and Dahlia Shuhaibar

Canadian Cases in Private International Law in 2020 / Jurisprudence canadienne en matière de droit international privé en 2020

Joost Blom

\section{Book Reviews / Recensions de livres}

Treaties in Motion: The Evolution of Treaties from Formation to Termination, by Malgosia Fitzmaurice \& Panos Merkouris André-Philippe Ouellet

Domestic Courts and the Interpretation of International Law: Methods and Reasoning Based on the Swiss Example, by Odile Ammann

Le dialogue entre les juridictions et quasi-juridictions internationales de protection des droits de la personne: L'exemple de la prohibition de la torture et autres peines ou traitements cruels, inhumains ou dégradants, par Silviana Cocan

Abir Elmekki

The Elgar Companion to the International Criminal Court, edited by Margaret M. deGuzman \& Valerie Oosterveld Gillian MacNeil

Corporate Environmental Accountability in International Law, 2nd ed., by Elisa Morgera

Emily Cook-Bielech

682 